\title{
Genetic and phenotypic relationships between physiological traits and performance test traits in sheep
}

\author{
ND Cameron, E Cienfuegos-Rivas \\ AFRC Roslin Institute (Edinburgh), Roslin, Midlothian, EH25 9PS, UK
}

(Received 3 November 1992 ; accepted 12 November 1993)

\begin{abstract}
Summary - Genetic and phenotypic relationships between physiological traits and performance test traits were estimated with data from lines of Texel-Oxford sheep divergently selected for carcass lean content, for the identification of physiological predictors of genetic merit for carcass lean content. At the end of the performance test, blood samples were taken from 151 animals, the progeny of 31 sires, when fed and when fasted for 30 and $54 \mathrm{~h}$. Heritability estimates for traits associated with protein metabolism, creatinine, urea and insulin-like growth factor-1 (IGF-1), were higher with ad-libitum feeding than heritabilities of traits associated with lipid and energy metabolism, $\beta$-hydroxybutyrate, non-esterified fatty acids, triglyceride and glucose. Several physiological traits, $\beta$-hydroxybutyrate, creatinine and insulin-like growth factor-1 (IGF-1), were moderately correlated with the performance test traits of liveweight and muscle depth, but only urea and insulin-like growth factor-1 were significantly correlated with backfat depth. Correlations between physiological traits and predicted carcass composition were estimated, as animals were required for breeding or were allocated to another experiment. Based on phenotypic correlations, $\beta$-hydroxybutyrate and IGF-1 may be useful indicators of merit for predicted carcass lean weight, with urea being an indicator of predicted carcass lean content. Measurement of physiological traits when animals were fasted may not be required for the prediction of genetic merit using physiological traits, as genetic correlations between feeding and fasting were high in absolute value for all physiological traits, except glucose.
\end{abstract}

sheep / genetic parameter / physiological trait / carcass composition

Résumé - Relations génétiques et phénotypiques entre des caractères physiologiques et des performances chez le mouton. Les relations génétiques et phénotypiques entre des caractères physiologiques et des performances ont été estimées sur des données provenant de lignées ovines Texel-Oxford sélectionnées de manière divergente pour la teneur en maigre de la carcasse, en vue d'identifier des prédicteurs physiologiques de la valeur génétique pour la teneur en maigre de la carcasse. Au terme du contrôle individuel (associant des mesures de poids vif et d'épaisseurs de gras et de muscle mesurées par ultra-sons), des échantillons de sang ont été prélevés sur 151 animaux, descendant de 31 pères, et étant soit alimentés soit à jeun depuis 30 et $54 \mathrm{~h}$. Les estimées d'héritabilité pour des caractères associés au métabolisme protéique avec alimentation à volonté - créatinine, urée et 
somatomédine (IGF-1) - sont plus élevées que les héritabilités de caractères associés au métabolisme énergétique et lipidique, tels que $\beta$-hydroxybutyrate, acides gras non estérifiés, triglycérides et glucose. Plusieurs caractères physiologiques, $\beta$-hydroxybutyrate, créatinine et IGF-1, sont modérément corrélés avec les performances individuelles de poids vif et d'épaisseur de gras. Les corrélations entre les caractères physiologiques et la composition prédite de la carcasse ont été estimées, puisque les animaux étaient soit mis à la reproduction soit destinés à une autre expérience. Sur la base des corrélations phénotypiques, le $\beta$-hydroxybutyrate et l'IGF-1 peuvent être considérés comme des indicateurs intéressants de la teneur en maigre de la carcasse. La mesure de caractères physiologiques après mise à jeun n'est pas requise pour prédire la valeur génétique, puisque les corrélations génétiques entre les conditions de jeûne et d'alimentation normale sont élevées en valeur absolue pour tous les caractères physiologiques à l'exception du glucose.

mouton / paramètre génétique / caractère physiologique / composition de la carcasse

\section{INTRODUCTION}

Genetic improvement of lean growth rate in sheep breeding programmes requires predictors of genetic merit for carcass traits. Selection criteria have included whole animal measurements, such as liveweight with ultrasonic backfat and muscle depths (Bennet et al, 1988; Cameron and Bracken, 1992; Kadim et al, 1989; Simm et al, 1990). Physiological traits may provide additional information for estimation of genetic merit for lean growth (Land, 1981; Blair et al, 1990).

Several studies have examined differences in physiological traits between particular genotypes, to identify traits as indicators of genetic merit. For example, lower urea concentrations have been reported in selection lines of high genetic merit for protein deposition (lean meat or wool) or secretion (milk) than in lines of low genetic merit in sheep (Bremmers et al, 1988; Cameron, 1992; Carter et al, 1989; Clark et al, 1989; Van Maanen et al, 1989), in pigs (Mersmann et al, 1984) and in dairy cattle (Tilakaratne et al, 1980; Sejrsen et al, 1984; Sinnett-Smith et al, 1987).

Phenotypic and genetic parameters for physiological traits and phenotypic correlations with performance test traits of sheep in 2 divergently selected lines for carcass lean content were estimated. There may be genetic variation in sensitivity or responsiveness to homeostatic factors in the control of metabolism (Bauman and Currie, 1980), such that the correlation between a physiological trait and the selection objective may be higher under one feeding regime than another. Therefore, physiological traits were measured under fed and under fasted conditions. The study was not able to estimate genetic relationships between physiological traits and production traits, as carcass information was not available, because animals were either required for breeding or were allocated to another experiment. 


\section{MATERIALS AND METHODS}

\section{Animals}

A divergent selection experiment was started in 1985 with a Texel-Oxford flock and the selection criterion was designed to change body composition without a corresponding change in liveweight at 20 weeks of age. A detailed description of the establishment of the selection lines, the ram performance test and the selection procedures is given by Cameron and Bracken (1992). Selection was based on ram performance only and, by 1988 , the selection line difference in the selection criterion was $0.62 \mathrm{sd}$ with a generation interval of $1.85 \mathrm{yr}$.

In 1988, 1989 and 1990, a total of 151 performance tested rams were measured for several physiological traits, with 32,25 and 23 rams from the lean line in the $3 \mathrm{yr}$ and 34,17 and $20 \mathrm{rams}$ from the fat line. On average, there were 5 sire families each year in both selection lines and the rams were progeny of 31 sires. There were physiological measurements on the sires of $85 \mathrm{rams}$, as selected rams were mated at 6 months of age. After weaning at 8 weeks of age, rams were penned and fed to appetite, twice a day, until the end of test at 20 weeks of age. Early weaning was practised to lessen maternal effects on ram performance test and a high energy $(12 \mathrm{MJ} / \mathrm{kg} \mathrm{DM})$ and high protein $(180 \mathrm{~g} / \mathrm{kg} \mathrm{DM}$ crude protein) ration was fed to reduce nutritional constraints on the rams' genetic ability for protein and lipid deposition on test. At the end of the test, liveweight (WT), ultrasonic subcutaneous fat depth (FD) and longissimus dorsi muscle depth (MD) were recorded. Carcass lean weight $(\mathrm{kg})$ and content $(\mathrm{g} / \mathrm{kg})$ were predicted from performance test traits, using regression equations derived by Cameron and Bracken (1992) for the TexelOxford flock, as carcass information was not available on performance tested rams in the current study. Regression equations from the study of Cameron and Bracken (1992) were:

Carcass lean weight $(\mathrm{kg})=$ constant $+0.11 \mathrm{WT}-0.13 \mathrm{FD}+0.13 \mathrm{MD}$

Carcass lean content $(\mathrm{g} / \mathrm{kg})=$ constant $-0.32 \mathrm{WT}-13.7 \mathrm{FD}+4.0 \mathrm{MD}$

and the proportional reductions in variance of carcass lean, for animals in the Cameron and Bracken (1992) study, due to the regression equations were 0.57 and 0.49 , respectively.

\section{Measurement of physiological traits}

The day after ultrasonic scanning, animals were fed as normal at $0800 \mathrm{~h}$ and then fasted for $54 \mathrm{~h}$. Blood samples were taken on each of $3 \mathrm{~d}$ at $1430 \mathrm{~h}$, at which time measurements were most repeatable (Cameron, 1992). At each sampling period, 5 -ml blood samples were collected by jugular venipuncture, using vacutainers, and after overnight storage to allow clotting, serum was separated by centrifugation. The physiological traits measured were $\beta$-hydroxybutyrate (BHB) and glucose (GLUC), as indicators of energy balance, non-esterified fatty acids (NEFA) and triglyceride (TRIG), as intermediaries of lipid metabolism, creatinine (CREA) and urea (UREA), as indicators of protein degradation, and insulin-like growth factor-1 (IGF). Details of assay methodologies are given by Cameron (1992). 
Serum IGF concentrations were determined by radioimmunoassay (Armstrong et $a l, 1990$ ) following extraction procedures of Daughaday et al (1980) (DProc) and Enright et al (1989) (EProc) for the samples taken in 1988 and in 1989 and 1990, respectively. Enright et al (1989) reported that their procedure was more efficient in separating IGF from its binding protein complex than DProc and that serum IGF concentrations using DProc would be overestimated by radioactivity associating with binding protein complex. A subset of 25 samples from 1988, which uniformly covered a wide range of IGF values, were re-assayed using EProc to determine an adjustment for the 1988 values to be compatible with the 1989 and 1990 values, as not all 1988 samples were available for re-assay using EProc. The mean and variance for DProc samples was larger than for EProc samples, as expected, and the correlation coefficient of 0.88 (se 0.21 ) indicated that a linear adjustment of DProc samples was appropriate. The regression coefficient was equal to 0.505 (se 0.020 ), with the regression forced through the origin, which was consistent with EProc being $42 \%$ more efficient than DProc, as reported by Enright et al (1989). IGF values from DProc in 1988 were adjusted accordingly, and the within-animal sd of adjusted 1988 IGF values (0.065) was similar to those for 1989 and 1990 IGF values (0.056 and 0.053).

\section{Statistical analyses}

Power transformations of the data were examined using methodology suggested by Solomon (1985), as between-animal variation in the physiological response to fasting may have resulted in the data not satisfying the assumptions of a linear mixed model. The method identified a power transformation which maximised the log likelihood under the joint hypotheses of (i) independence of mean and variance, (ii) normality, and (iii) additivity under the proposed model.

For a given physiological trait, $x$, the transformed trait, $y$, was equal to $y=$ $\left(x^{\lambda}-1\right) / \lambda$ for $\lambda \neq 0$ and $y=\log x$ for $\lambda=0$. An approximate $\log$ likelihood equal to:

$$
-0.5(N-s) \log (\mathrm{MSE})-0.5 s \cdot \log (\mathrm{MSS})+(\lambda-1) \Sigma \log x
$$

was used, where MSE and MSS were the residual and between-sire mean squares, respectively, from the analysis of variance of transformed data, with fixed effects included in the model; $N$ and $s$ were the total numbers of animals and sires, and $(\lambda-1) \Sigma \log x$ was the Jacobian of the transformation. The $\lambda$ value, which maximised the log likelihood, $\lambda_{\max }$, was determined by differentiation of the quadratic function, describing the log likelihood in terms of $\lambda$.

For each transformed physiological trait, fixed effects, genetic and phenotypic (co)variances for the 3 sampling days were estimated by residual maximum likelihood (REML) (Patterson and Thompson, 1971) analyses, using the multivariate REML program of Meyer (1985). An individual animal model was fitted, which included the fixed effects of selection line, year of measurement, dam age $(1,2,3$ or $4 \mathrm{yr}$ of age) and birth type (single and twin). The performance test was on a fixed age basis, 8-20 weeks of age, such that weight at the start of test was not included in the model as a covariate. Divergence between selection lines in the first year of the study was accounted for by inclusion of selection line in the model. Meyer and Hill (1991) used the same procedure, in the analysis of a selection experiment, to 
account for selection in generations 0 and 1 , as records from those generations were not used in the analyses.

The rate of convergence in the REML analyses was improved by scaling the traits, so that phenotypic variances of all traits were of the same order of magnitude. Iterations were assumed to have converged when the maximum proportional difference between iterations in genetic variance components on the canonical scale was less than $10^{-5}$. Sampling errors of genetic parameters were determined from variances of the variance components (Meyer, 1985). Inclusion of performance test traits, on which selection had been practised, and incorporation of pedigree information in the multivariate analysis of each physiological trait, accounted for the continued selection (Sorensen and Kennedy, 1986; Kennedy, 1990). However, in the multivariate analyses of physiological traits and predicted carcass lean weight and content, the 3 performance test traits were not included, as the predicted carcass traits were linear functions of performance test traits.

\section{RESULTS}

\section{Physiological traits}

Within-sampling day means and residual sd after fitting fixed effects, for each physiological trait are presented in table I. Between feeding and fasting for $54 \mathrm{~h}$, BHB, NEFA and TRIG increased, while GLUC and IGF decreased. UREA was highest $30 \mathrm{~h}$ after fasting.

Table I. Means and standard deviations $(\mathrm{mmol} / \mathrm{l})$ for physiological traits within sampling day.

\begin{tabular}{llccccc}
\hline & \multicolumn{2}{c}{$\begin{array}{c}\text { Normal feeding } \\
\text { sampling } d 1\end{array}$} & \multicolumn{2}{c}{ Fasted $30 h$} & \multicolumn{2}{c}{ Fasted $54 h$} \\
& Mean & $S D^{\mathrm{a}}$ & Mean & $S D$ & Mean & SD \\
\hline B-Hydroxybutyrate & 0.30 & 0.105 & 0.42 & 0.092 & 0.61 & 0.104 \\
Non-esterified fatty acids & 0.20 & 0.111 & 1.34 & 0.395 & 1.59 & 0.415 \\
Triglyceride & 0.22 & 0.077 & 0.28 & 0.066 & 0.36 & 0.094 \\
Glucose & 3.63 & 0.581 & 2.99 & 0.454 & 2.76 & 0.405 \\
Creatinine & 0.10 & 0.015 & 0.11 & 0.015 & 0.11 & 0.015 \\
Urea $_{\text {Insulin-like growth factor-1 }}{ }^{\mathrm{b}}$ & 8.6 & 1.86 & 12.0 & 2.45 & 10.3 & 2.05 \\
& 0.54 & 0.124 & 0.47 & 0.129 & 0.34 & 0.115 \\
\hline
\end{tabular}

a $\mathrm{SD}$ are equal to the residual sd from a model which included fixed effects only; ${ }^{\mathrm{b}}$ measurements in $\mu \mathrm{g} / \mathrm{ml}$.

Standard deviations of NEFA were substantially higher with fasting than with feeding but variation in GLUC decreased with fasting (table I). Although there were differences in residual variances, for the remaining traits, the differences were not statistically significant. 


\section{Transformation of traits}

The $\lambda_{\max }$ values, which maximised the within-sampling day log likelihoods, are given in table II. There was considerable between-sampling day variation in $\lambda_{\max }$ values for BHB, NEFA and CREA but the $\lambda_{\max }$ values for other traits were relatively constant between sampling days.

Table II. Within-sampling day $\lambda_{\max }$ value of each physiological trait, the $\lambda$ value corresponding to a simple transformation and twice the difference (DIF) between the 2 log likelihoods.

\begin{tabular}{|c|c|c|c|c|c|c|c|c|c|}
\hline & \multicolumn{3}{|c|}{$\begin{array}{l}\text { Normal feeding } \\
\text { sampling } d 1\end{array}$} & \multicolumn{3}{|c|}{$\begin{array}{r}\text { Fasted } 30 h \\
\text { sampling d } 2\end{array}$} & \multicolumn{3}{|c|}{$\begin{array}{r}\text { Fasted } 54 \mathrm{~h} \\
\text { sampling d } 3\end{array}$} \\
\hline & $\lambda_{\max }$ & $\lambda$ & $D I F$ & $\lambda_{\max }$ & $\lambda$ & $D I F$ & $\lambda_{\max }$ & $\lambda$ & $D I F$ \\
\hline$\beta$-Hydroxyl & -0.21 & 0 & $1.2^{\mathrm{a}}$ & 0.57 & 0.5 & 0.0 & -0.20 & 0 & 0.2 \\
\hline Non-esterified fatty acids & 0.15 & 0 & 1.6 & 0.42 & 0.5 & 0.1 & 0.30 & 0.5 & 0.8 \\
\hline Triglyceride & 0.04 & 0 & 0.1 & 0.06 & 0 & 0.0 & -0.18 & 0 & 0.4 \\
\hline Glucose & 2.02 & 2 & 0.4 & 1.76 & 2 & 0.5 & 2.06 & 2 & 0.6 \\
\hline Creatinine & 0.74 & 1 & 0.6 & 0.32 & 0 & 0.3 & -0.60 & 0 & 1.2 \\
\hline Urea & 0.25 & 0 & 1.0 & -0.05 & 0 & 0.0 & -0.03 & 0 & 0.0 \\
\hline Insulin-like growth factor-1 & 0.68 & 1 & 1.5 & 0.88 & 1 & 0.3 & 0.82 & 1 & 1.4 \\
\hline
\end{tabular}

${ }^{\text {a }}$ DIF has a $\chi_{1}^{2}$ distribution and the 0.05 significance level is equal to 3.84 .

Within-sampling day differences between the maximum log likelihood and the $\log$ likelihoods with a $\log$, square root or no transformation of each trait were examined to determine if a simple transformation could be applied (table II), as Solomon (1985) suggested that the use of simple $\lambda$ values would be practicable. One transformation for each trait on all sampling days was sufficient for TRIG, GLUC, UREA and IGF. A different transformation on $\mathrm{d} 1$ compared to $\mathrm{d} 2$ and $\mathrm{d} 3$ was required for NEFA and CREA. For BHB, a log transformation was used for d 1 and $\mathrm{d} 3$, but a square root transformation on $\mathrm{d} 2$.

After transformation, the distribution of each trait was normal, in terms of skewness and kurtosis coefficients. For each transformed trait, skewness and kurtosis coefficients were not statistically significantly different from 0 and 3 , respectively, the values for a normal distribution. In general, the relative reduction in skewness coefficients, due to transformations, was greater than the change in kurtosis coefficients. For example, the skewness and kurtosis coefficients for BHB with feeding changed from 1.26 to 0.27 and 5.03 to 3.36 , respectively.

\section{Fixed effects}

Effects of selection line, dam age and birth type on transformed physiological traits, with feeding of animals, and performance test traits are given in table III. Mean values (phenotypic sd) for the performance test traits of liveweight were $48.8 \mathrm{~kg}(5.9)$, with $25.5 \mathrm{~mm}(2.2)$ and $4.2 \mathrm{~mm}$ (1.0) for ultrasonic muscle and fat depths, respectively. The lean line had lower serum concentrations of NEFA, 
TRIG and UREA, but the lean line had lower backfat depths, even though there was no selection line difference in liveweight. Progeny of older dams had higher concentrations of CREA, UREA and IGF, with smaller differences of opposite sign for twin-born animals. Single-born progeny from older ewes were heavier, with greater ultrasonic muscle and backfat depths.

Table III. Estimates of fixed effects for physiological traits, on the transformed scale with normal feeding, and estimates for liveweight (WT), ultrasonic muscle (MD) and backfat (FD) depth.

\begin{tabular}{|c|c|c|c|c|c|c|c|c|c|c|}
\hline & \multirow{2}{*}{\multicolumn{7}{|c|}{ Fixed effect }} & \multirow{2}{*}{\multicolumn{3}{|c|}{ Performance tes }} \\
\hline & & & & & & & & & & \\
\hline & $B H B$ & $N E F A$ & $T R I G$ & $G L U C$ & $C R E A$ & $U R E A$ & $I G F$ & $W T$ & $M D$ & $F D$ \\
\hline \multirow{2}{*}{$\begin{array}{l}\text { Selection line: lean } \\
\text { sed }\end{array}$} & 0.5 & -2.5 & -1.0 & 0.5 & -0.2 & -0.7 & 0.1 & 0.1 & 0.2 & -0.8 \\
\hline & 0.5 & 0.8 & 0.5 & 0.6 & 0.1 & 0.3 & 0.1 & 0.9 & 0.3 & 0.2 \\
\hline \multirow{2}{*}{$\begin{array}{l}\text { Dam age: } \geqslant 2 y r \\
\text { sed }\end{array}$} & $-1.2^{\mathrm{a}}$ & 0.0 & 0.2 & 1.8 & 0.8 & 1.2 & 0.6 & 5.4 & 1.4 & 0.6 \\
\hline & 1.0 & 1.8 & 1.1 & 1.2 & 0.3 & 0.6 & 0.3 & 1.9 & 0.5 & 0.3 \\
\hline \multirow{2}{*}{$\begin{array}{l}\text { Birth type: twin } \\
\text { sed }\end{array}$} & $0.4^{\mathrm{b}}$ & 1.4 & 1.6 & 0.0 & -0.4 & -0.1 & -0.4 & -5.0 & -0.8 & -0.5 \\
\hline & 0.6 & 1.0 & 0.6 & 0.7 & 0.1 & 0.3 & 0.2 & 1.1 & 0.3 & 0.2 \\
\hline
\end{tabular}

a Difference between lamb from a 1-yr-old ewe and a ewe at least 2-yr-old, values for 2-, 3 - and 4-yr-old ewes were similar and have been combined; ${ }^{b}$ difference between a twinand single-born lamb.

\section{Phenotypic and genetic parameter estimates for physiological traits}

Within-sampling day heritability estimates for physiological traits are given in table IV. Under normal feeding, heritability estimates for traits associated with protein metabolism, CREA, UREA and IGF, were higher than for GLUC and traits associated with lipid metabolism, BHB, NEFA and TRIG. Within-trait, betweensampling day phenotypic and genetic correlations are presented in table IV. The positive phenotypic correlations between feeding and fasting were higher for traits associated with protein metabolism than those involved in lipid metabolism.

Genetic correlations between feeding and fasting were high in absolute value for all physiological traits, except GLUC. Correlations for NEFA and TRIG between the 2 fasting days were lower in magnitude than between feeding and fasting, and conversely for GLUC. The negative correlation between feeding and fasting for NEFA was consistent with selection line differences on each sampling day (Cameron, 1992), as during feeding the lean line had lower NEFA concentrations than the fat line, but on fasting the lean line had higher values.

\section{Phenotypic correlations between physiological and performance traits}

Phenotypic correlations between certain physiological and performance test traits are given in table $\mathrm{V}$. Correlations between performance test traits with NEFA, TRIG and GLUC were less than 0.20, in absolute value, and are not presented. 
ND Cameron et al

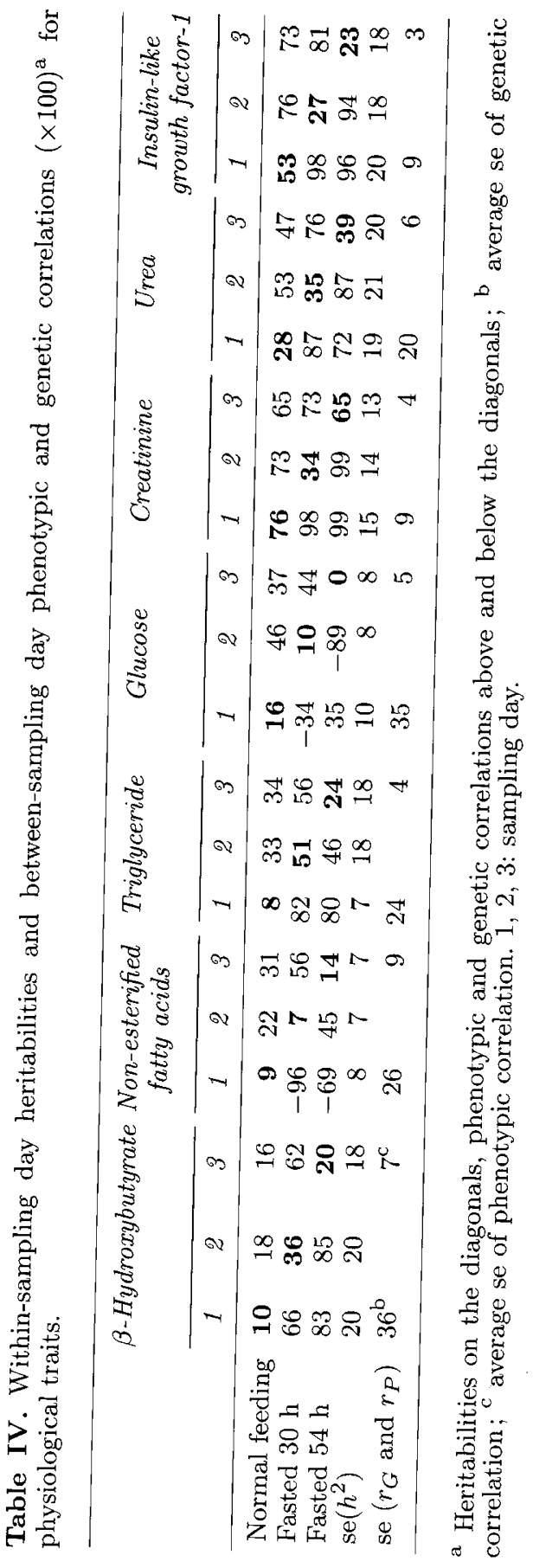


BHB, CREA and IGF were moderately correlated with liveweight and muscle depth, but only UREA and IGF were significantly correlated with backfat depth. On fasting, correlations for $\mathrm{BHB}$ and CREA with liveweight and muscle depth were smaller compared to normal feeding, while UREA became negatively correlated with no change in the IGF correlations. Phenotypic correlations between BHB, CREA, UREA and IGF with predicted carcass lean weight were similar to the correlations with liveweight (table V), but only UREA was significantly correlated with predicted carcass lean content, due to the negative correlation with backfat depth.

Table V. Phenotypic correlations $(\times 100)$ for physiological traits with performance test traits and predicted carcass lean ${ }^{\mathrm{a}}$, within-sampling day.

\begin{tabular}{|c|c|c|c|c|c|c|c|c|c|c|c|c|}
\hline & \multicolumn{3}{|c|}{$\beta$-Hydroxybutyrate } & \multicolumn{3}{|c|}{ Creatinine } & \multicolumn{3}{|c|}{ Urea } & \multicolumn{3}{|c|}{$\begin{array}{l}\text { Insulin-like } \\
\text { growth factor-1 }\end{array}$} \\
\hline & 1 & 2 & 3 & 1 & 2 & 3 & 1 & 2 & 3 & 1 & 2 & 3 \\
\hline Liveweight & $-38^{b}$ & -12 & -8 & 24 & 9 & 3 & 25 & -6 & -13 & 32 & 38 & 37 \\
\hline Muscle depth & $-\mathbf{3 7}$ & -20 & -10 & 22 & 7 & 14 & 7 & -16 & -12 & 42 & 40 & 35 \\
\hline Backfat depth & -17 & 2 & 6 & 2 & 5 & -1 & 21 & 9 & 3 & 24 & $\mathbf{2 3}$ & 20 \\
\hline Lean weight & -41 & -19 & -12 & 26 & 8 & 8 & 19 & -13 & -16 & 38 & 42 & 41 \\
\hline Lean content & 1 & -11 & -10 & 11 & 0 & 11 & -19 & -17 & -8 & -3 & -3 & 4 \\
\hline se correlation & $8^{\mathrm{c}}$ & 8 & 8 & 7 & 8 & 7 & 9 & 9 & 9 & 7 & 7 & 7 \\
\hline
\end{tabular}

${ }^{\mathrm{a}}$ Predicted carcass lean weight $(\mathrm{kg})$ and predicted carcass lean content $(\mathrm{g} / \mathrm{kg}) ;{ }^{\mathrm{b}}$ correlations in bold were statistically significantly different from zero; ${ }^{\mathrm{c}}$ average se of phenotypic correlation. 1, 2, 3: sampling day.

\section{DISCUSSION}

Heritability estimates for physiological traits involved in protein metabolism, CREA, UREA and IGF, indicate that there is substantial genetic variation in these traits. There is little comparable information on heritability estimates for physiological traits associated with growth in sheep (Woolliams et al, 1984), as the majority of studies have examined the role of gonadotrophins as predictors of genetic merit for reproductive traits (Land et al, 1988). Correlated responses in physiological traits to selection for growth and/or fat deposition have been studied, but heritabilities have not been previously estimated. Similarly, there are few estimates of correlations between performance test traits and physiological traits. The association between muscle depth and CREA was reported by Hanset and Michaux (1986) for cattle, with CREA suggested as an indicator of carcass lean mass. A negative relationship between UREA and protein deposition has been reported in several studies (Bremmers et al, 1988; Carter et al, 1989; Clark et al, 1989; Van Maanen et al, 1989; Cameron, 1992), which is consistent to an extent, with a positive correlation between UREA and backfat depth. 
Based on phenotypic correlations, UREA may be a useful predictor of carcass lean content with BHB and IGF as predictors of carcass lean weight. Measurement of physiological traits when animals were fasted may not be required for the prediction of genetic merit using physiological traits, as genetic correlations between feeding and fasting were high in absolute value for all physiological traits, except GLUC. Further, the phenotypic correlations between physiological and performance test traits were of greater magnitude with normal feeding, which also suggests that fasting would not be necessary when measuring physiological traits as predictors of genetic merit. Precise estimates of the genetic correlations between the physiological traits and carcass composition are required for calculation of appropriate selection criteria, to combine performance test traits with physiological traits. Genetic correlations were estimated in this study, but standard errors of the estimates were sufficiently large, such that the correlations were of limited value.

Although the performance test incorporated early weaning, in an attempt to reduce maternal effects, there were still effects of dam age and birth type on the performance test and physiological traits. However, the effects of dam age and birth type on the performance of intensively tested rams were markedly less than on extensively tested rams, suggesting that the intensive performance test had certainly reduced maternal effects. For example, in a genotype with environment study in 1991 the proportional difference in backfat depth due to dam age (1-yrold versus older dams) was 0.36 for 53 ram lambs tested at grass with their dams, relative to the mean backfat depth of $1.8 \mathrm{~mm}$, while for 44 rams on the intensive performance test the corresponding values were 0.15 and $2.5 \mathrm{~mm}$. Similarly, the proportional differences between single- and twin-born lambs were 0.49 and 0.12 . Estimation of an animal's genetic merit for protein and lipid deposition based on performance test and physiological traits would be biased by the effects of dam age and birth type, so they were included in the model to remove their effects on the measured traits. The positive correlation for liveweight with CREA, UREA and IGF, with animals on normal feeding, may partially explain the effect of dam age and birth type on these traits, since single lambs were heavier than twin lambs as were progeny of older dams. Morel et al (1991) also reported an effect of dam age and birth type on IGF.

Physiological predictors of genetic merit for carcass content may be identified by examining correlated responses to selection for carcass lean or by selecting on a potentially useful physiological trait and measuring the correlated response in carcass content. Hill (1985) considered the former approach, as used in the present study, preferable to the latter. Blair et al (1990) established divergent selection lines for IGF in sheep and Morel et al (1991) reported a realised heritability of 0.27 for IGF. The IGF heritability estimate from the current study, 0.53, may be higher than the Morel et al (1991) estimate for at least 3 reasons. Data in the Morel et al (1991) study may not have been normally distributed, which may have resulted in a lower heritability estimate than from transformed data (see below). Animals in the Morel et al (1991) study were performance tested on grass, rather than on a high protein and energy ration as in the present study, which may have constrained expression of genetic variation in serum IGF concentration. Animals in the present study were blood sampled at 20 weeks of age, while those in the Morel et al (1991) study were sampled at approximately 4 months of age. Morel et al (1991) reported 
a positive association between age at sampling and IGF, which suggests that it is important to standardise the test procedure for the identification of physiological predictors of genetic merit for carcass composition.

Between-breed differences in adipose tissue metabolism have provided information on the metabolic basis for genetic variation in fat deposition (SinnettSmith and Woolliams, 1988), but each breed had a unique combination of anabolic and catabolic processes. Therefore, if physiological traits associated with lipid metabolism are identified as predictors of genetic merit, based on a withinbreed difference between divergent selection lines, then they may be breed specific. Heritabilities for traits associated with protein metabolism, under normal feeding, were higher than for traits associated with lipid metabolism, in the current study. Similar results have been reported in pigs (Lingaas et al, 1992), although not in cattle (Bittante et al, 1987; Bishop et al, 1992). Therefore, the relatively greater genetic variation in components of protein metabolism suggests that study of regulatory factors for protein metabolism may identify predictors of genetic merit for carcass lean content in sheep. For example, Cameron (1992) suggested that, when fasted, animals from the fat selection line made relatively more use of products from protein catabolism as glucose precursors, than those of the lean line.

For each physiological trait, a series of power transformations was used to identify a transformation which maximised the log likelihood with a mixed model. The transformations were justified on statistical reasons, although they may have an underlying genetic or biological basis. Log transformations were required for traits associated with fat metabolism, but not for CREA under normal feeding. Lingaas et al (1992) reported that log transformations were necessary for NEFA and TRIG, but not for CREA measurements in pigs. In dairy cattle, log transformations of NEFA, TRIG and UREA were required, but not for BHB and GLUC (Woolliams et al, 1992). Heritability estimates for traits associated with fat metabolism were low, with transformed data, but the results of Ibe and Hill (1988) suggest that heritability estimates with untransformed data would be even lower. Hill et al (1983) reported higher heritability estimates for log milk yield than for milk yield, which was attributed to increased homogeneity of phenotypic variance between herds. Similarly, the genetic (co)variances for physiological traits with production traits may be underestimated, if the data have not been transformed to ensure normality and homogeneity of within-sire variances.

\section{ACKNOWLEDGMENTS}

RS Nisbet carried out all the assays except for insulin-like growth factor-1, which was assayed by $\mathrm{K}$ Angus. J Bracken managed the sheep performance test and blood sampled the sheep. The constructive comments of referees were appreciated. The Ministry of Agriculture, Fisheries and Food provided funding for this research project.

\section{REFERENCES}

Armstrong DG, Duclos MJ, Goddard C (1990) Biological activity of insulin-like growth factor-1 purified from chicken serum. Domest Anim Endocrinol 7, 383-393 
Bauman DE, Currie WB (1980) Partitioning of nutrients during pregnancy and lactation: a review of mechanisms involving homeostasis and homeorhesis. $J$ Dairy Sci 63, 1514-1529

Bennett GL, Meyer HH, Kirton AH (1988) Effects of selection for divergent ultrasonic fat depth in rams on progeny fatness. Anim Prod 47, 379-386

Bishop SC, Broadbent JS, Kay RM, Rigby I (1992) Blood metabolite concentrations in Hereford $\times$ Friesian offspring of bulls selected for lean growth rate and lean food conversion efficiency. J Anim Breed Genet 109, 207-215

Bittante G, Buttazzoni L, Spanghero M, Aleandri R (1987) Heritability of some blood variables and relationship with the performance traits of Italian Simmental young bulls. In: Performance testing of AI bulls for efficiency and beef production in dairy and dual-purpose breeds. Proc EAAP Seminar 27-29 April 1987, Wageningen, Netherlands, 146-149

Blair HT, McCutcheon SN, Mackenzie DDS (1990) Components of the somatotropic axis as predictors of genetic merit for growth. Proc 4th World Congr Genetics Appl Livest Prod Edinburgh, July 23-27, 1990, vol XVI, 246-255

Bremmers RP, Morgan PF, McCutcheon SN, Purchas RW (1988) Effects of plane of nutrition on energy and nitrogen retention and on plasma urea concentration in Southdown ram hoggets from high and low backfat selection lines. NZ J Agric Res $31,1-7$

Cameron ND (1992) Correlated physiological responses to selection for carcass lean content in sheep. Live Prod Sci 30, 53-68

Cameron ND, Bracken J (1992) Selection for carcass lean content in a terminal sire breed of sheep. Anim Prod 54, 367-377

Carter ML, McCutcheon SN, Purchas RW (1989) Plasma metabolite and hormone concentrations as predictors of genetic merit for lean meat production in sheep: effects of metabolic challenges and fasting. NZ J Agric Res 32, 343-353

Clark CM, Mackenzie DDS, McCutcheon SN, Blair HT (1989) Physiological responses to selection for greasy fleeceweight in Romney sheep. NZ J Agric Res 32, 29-36

Daughaday WH, Mariz IK, Blethen SL (1980) Inhibition of access of bound somatomedin to membrane receptor and immunobinding sites: a comparison of radioreceptor and radioimmunoassay of somatomedin in native and acid-ethanolextracted serum. J Clin Endocrinol Metab 51, 781-788

Enright WJ, Chapin LT, Moseley WM, Zinn SA, Kamdar MB, Krabill LF, Tucker HA (1989) Effects of infusions of various doses of bovine-growth-hormone-releasing factor on blood hormones and metabolites in lactating Holstein cows. $J$ Endocrinol $122,671-679$

Hanset R, Michaux C (1986) Characterisation of biological types of cattle by the blood levels of creatine and creatinine. J Anim Breed Genet 103, 227-240

Hill WG, Edwards MR, Ahmed MKA, Thompson R (1983) Heritability of milk yield and composition at different levels and variability of production. Anim Prod $36,59-68$

Hill WG (1985) Detection and genetic assessment of physiological criteria of merit within breeds. In: Genetics of Reproduction in Sheep (RB Land, DW Robinson, eds) Butterworth Scientific, London, 319-331 
Ibe SN, Hill WG (1988) Transformation of poultry egg production data to improve normality, homoscedasticity and linearity of genotypic regression. $J$ Anim Breed Genet 105, 231-240

Kadim IT, Purchas RW, Rae AL, Barton RA (1989) Carcass characteristics of Southdown rams from high and low backfat selection lines. NZ J Agric Res 32, 181-191

Kennedy BW (1990) Use of mixed model methodology in analysis of designed experiments. In: Advances in Statistical Methods for Genetic Improvement of Livestock (D Gianola, K Hammond, eds), Springer-Verlag, Berlin, 77-97

Land RB (1981) Physiological criteria and genetic selection. Livest Prod Sci 8, 203-213

Land RB, Bodin L, Driancourt MA, Haley CS, McNeilly JR (1988) Physiological prediction of genetic merit for female reproduction in the sheep. In: Proc 3rd World Congr Sheep and Beef Cattle Breeding Paris, 19-23 June, 1988, vol 2, 611-622

Lingaas F, Brun E, Aarskaug T, Havre G (1992) Biochemical blood parameters in pigs. 2. Estimates of heritability for 20 blood parameters. J Anim Breed Genet 109, 281-290

Mersman HJ, Pond WG, Yen JT (1984) Use of carbohydrate and fat as energy source by obese and lean swine. J Anim Sci 58, 894-902

Meyer K (1985) Maximum likelihood estimation of variance components for a multivariate mixed model with equal design matrices. Biometrics 41, 153-165

Meyer K, Hill WG (1991) Mixed model analysis of a selection experiment for food intake in mice. Genet Res Camb 57, 71-81

Morel PCH, Blair HT, McCutcheon SN, Breier BH, Gluckman PD (1991) Responses to divergent selection for plasma insulin-like growth factor-1 (IGF-1) in sheep. Proc NZ Soc Anim Prod 51, 417-422

Patterson HD, Thompson R (1971) Recovery of inter-block information when block sizes are unequal. Biometrika 58, 545-554

Sejrsen K, Larsen F, Andersen BB (1984) Use of plasma hormone and metabolite levels to predict breeding value of young bulls for butterfat production. Anim Prod 39, 335-344

Simm G, Dingwall WS, Murphy SV, Fitzsimons J (1990) Selection for improved carcass composition in sheep. In: Proc 4th World Congr Genetics Appl Livest Prod. Edinburgh, July 23-27, 1990, vol XV, 100-104

Sinnet-Smith PA, Slee J, Woolliams JA (1987) Biochemical and physiological responses to metabolic stimuli in Friesian calves of differing genetic merit for milk production. Anim Prod 44, 11-19

Sinnet-Smith PA, Woolliams JA (1988) Genetic variations in subcutaneous adipose tissue metabolism in sheep. Anim Prod 47, 263-270

Solomon PJ (1985) Transformations for components of variance and covariance. Biometrika 72, 233-239

Sorensen D, Kennedy BW (1986) Analysis of selection experiments using mixed model methodology. J Anim Sci 63, 245-258

Tilakaratne N, Alliston JC, Carr WR, Land RB, Osmond TJ (1980) Physiological attributes as possible selection criteria for milk production. Anim Prod 30, 327-340 
Van Maanen MC, McCutcheon SN, Purchas RW (1989) Plasma metabolite and hormone concentrations in Southdown ram hoggets from lines divergently selected on the basis of backfat thickness. NZ J Agric Res 32, 219-226

Woolliams JA, Wiener G, Field AC (1984) The heritabilities and genetic correlations among eight blood constituents, and their relationship to aspects of performance and genetic polymorphisms, in the sheep. Anim Prod 38, 447-453

Woolliams JA, Nisbet RS, Lovendahl P (1992) The effect of dietary protein on metabolite concentrations during fasting calves differing genetically in dairy merit. Anim Prod 54, 175-181 